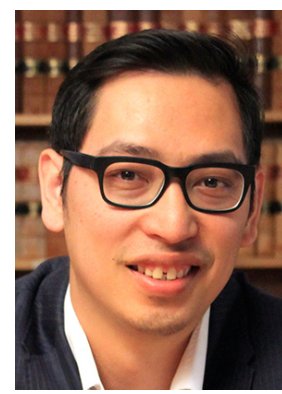

\title{
DISTANCE IS NO HURDLE: REFORMING THE FAMILY VIOLENCE EXCEPTION TO BETTER PROTECT IMMIGRANT WOMEN IN RURAL, REGIONAL AND REMOTE COMMUNITIES
}

\section{Khanh Hoang}

ANU Migration Law Program

ANU College of Law

Australia

\begin{abstract}
This article considers the impact of migration laws on immigrant women in rural, regional and remote communities (RRR communities) who are victims of family violence. The Migration Regulations 1994 (Cth) ('the Regulations') includes a 'family violence exception' that allows for the grant of permanent residency to women who hold a temporary partner visa in circumstances where the relationship with the Australian sponsor has broken down due to family violence. However, the Regulations impose strict procedural and evidentiary requirements for making a family violence claim. These laws disproportionately impact those in RRR communities by failing to account for their isolation, lack of access to services and particular vulnerabilities. As a result, immigrant women in RRR communities are restricted in their ability to access the family violence exception.
\end{abstract}

This article calls for reform of the Regulations to address the locational disadvantages faced by immigrant women in RRR communities. Building on the work of the Australian Law Reform Commission, it argues for the repeal of the provisions governing evidentiary requirements for 'non-judicially determined' claims of family violence. In its place, it is suggested that there should be no restrictions on the types of evidence that can be provided. In addition, all non-judicially determined family violence claims would be referred to an 'independent expert panel' for assessment. The independent expert panel should include, at a minimum, a number of community legal centres (CLCS) and family violence centres (FVCS) around Australia. CLCs and FVCs are leveraging technology - such as Skype and teleconferencing and integrated service responses to provide access to justice to those in RRR communities.

\section{Introduction}

In recent years, there has been an increased policy focus in Australia on reducing the prevalence of family violence against women. ${ }^{1}$ This has included, since 2010 , a raft of government reports calling for legislative and policy reform on the issue. ${ }^{2}$

In 2015, Rosie Batty was the recipient of the Australian of the Year Award for her work as an advocate for family violence reform. ${ }^{3}$ Around the same time, the state of Victoria instituted a Royal Commission into Family Violence, ${ }^{4}$ while Queensland established a Special Taskforce on Domestic and Family Violence. ${ }^{5}$ In

\footnotetext{
1 While men and women alike can experience family violence, the majority of those who suffer family violence are women. See Australian Bureau of Statistics, Personal Safety Survey Australia 2012, Cat No 4906.0 (2013) Experience of Partner Violence <http://www.abs.gov.au/ausstats/abs@.nsf/mf/4906.0>. While I have chosen to focus on the experience of immigrant women, male victims of family violence would benefit equally from the reforms proposed in this article.

2 Australian Government, 'The National Plan to Reduce Violence Against Women and Their Children 2010-2022' (2011). See also, The National Council to Reduce Violence Against Women and their Children, 'Time for Action: The National Council's Plan for Australia to Reduce Violence against Women and Their Children, 2009-2021' (Background Paper, March 2009). Family violence has also been the subject of two recent ALRC reports: Australian Law Reform Commission and New South Wales Law Reform Commission ((ALRC and NSWLRC), 'Family Violence - A National Legal Response' (ALRC Report No 114, 2010); ALRC and New South Wales Law Reform Commission (ALRC and NSWLRC) 'Family Violence and Commonwealth Laws - Improving Legal Frameworks' (ALRC Report No 117, 2012).

3 Australian Government, Australian of the Year 2015: Rosie Batty (2015) <http://www. australianoftheyear.org.au/honour-roll/?view=fullView\&recipientID=1179>.

4 Royal Commission into Family Violence (Victoria), The Commission <http://www.rcfv.com.au/The-Commission>. The Commission commenced its work on 22 February 2015 to inquire into and provide practical recommendations on how
} 
September 2015, the Australian Government unveiled a family violence package worth A\$100 million and called for 'urgent action' to address the issue. ${ }^{6}$ As a result, there is now considerable momentum and appetite for legislative and practical reforms to combat family violence.

Within this broader context, this article considers the impact of migration laws on immigrant women living in rural, regional and remote (RRR) communities who are victims of family violence. Ordinarily, immigrant women must hold a temporary partner visa for two years before transitioning to a permanent visa. However, the Migration Regulations 1994 (Cth) (the Regulations) provides for a 'family violence exception' that allows for the grant of permanent residency to women who hold a temporary partner visa in circumstances where the relationship with the Australian sponsor has broken down due to family violence.

The Regulations contain strict procedural and evidentiary requirements around who can provide evidence in support of a non-judicially determined family violence claim - including doctors, nurses, psychologist and the police - and the form that such evidence must take. These requirements disproportionately impact on those in RRR communities by falsely assuming that they have the same level of access to legal and social services as their urban counterparts. In practice, the law punishes those in RRR communities by failing to account for their isolation and particular vulnerabilities. The tyranny of distance is real for many immigrant women suffering family violence in RRR communities. Reform is necessary to remove the locational disadvantage for those in RRR communities and provide them with more equitable access to the family violence exception.

This article provides suggestions for reform. It proposes that the current requirements for making a valid 'non-judicially determined' claim of family violence in the Regulations be repealed. In its place, immigrant women should be able to submit any evidence in support of a non-judicially determined claim of family violence, which is then assessed by an 'independent expert panel'. This idea was considered, but not fully explored, by the Australian Law Reform Commission (ALRC) in 2012. Building on the ALRC's work, I argue that an independent expert panel should consist, at a minimum, of a number of community legal centres (CLCs) and family violence service centres (FVCs) around the country. CLCs and FVCs are leveraging technology - such as teleconferencing and Skype - and engaging in integrated service partnerships to overcome access to justice barriers for those living in RRR communities. The central thesis of this article is that, by leveraging these innovations and practices within CLCs and FVCs, the locational disadvantage faced by those in RRR areas can be remedied. The effect will be a meaningful opening up of access to the family violence exception for those living in RRR communities without putting at risk the integrity of the visa system.

\section{Immigrant women and family violence in rural, regional and remote communities}

It is well recognised that the prevalence of family violence has a significant flow-on costs to Australian society in terms of health, child welfare, homelessness and loss of economic contribution. ${ }^{7}$ Family violence was estimated to have cost the Australian economy $\$ 8.1$ billion in $2003,{ }^{8} \$ 13.1$ billion in 2009 , and projected to cost $\$ 15.6$ billion by $2021 .^{9}$ The most recent Australian Bureau of Statistics (ABS) personal safety survey in 2012 estimated that 41 per cent of women aged over 18 years have experienced some form of violence since the age of $15,{ }^{10}$ a further, 17 per cent have experience some form of sexual violence since the age of 15 and, in the majority of cases, at the hands of a perpetrator who was known to them. ${ }^{11}$

Victoria's responses to family violence can be improved. It is due to report to the Governor of Victoria by 29 February 2016 .

5 Special Taskforce on Domestic and Family Violence in Queensland, 'Not Now, Not Ever - Putting an End to Domestic and Family Violence in Queensland' (February 2015). The Taskforce commenced on 10 September 2014 and its report was released on 28 February 2015.

6 Malcolm Turnbull, Prime Minister, 'Women’s Safety Package to Stop the Violence' (Media Release, 24 September 2015).

7 Anna Dunkley and Janet Phillips, 'Domestic Violence in Australia: A Quick Guide to the Issues' (Research Paper Series, 2014-15, Australian Parliamentary Library, 26 March 2015).

8 Access Economics, 'The Cost of Domestic Violence to the Australian Economy: Part 1' (prepared for the Australian Government's Office of the Status of Women, 2004).

9 The National Council to Reduce Violence Against Women and their Children, 'The Cost of Violence Against Women and Their Children' (March 2009) 4

${ }^{10}$ Australian Bureau of Statistics, above n 1

11 Ibid. 
There is some evidence to suggest that the prevalence of family violence in Australia is greater in RRR communities vis-a-vis urban areas, although the data is by no means conclusive. ${ }^{12}$ However, what is clear from the research is that the view of a 'crime free rural life' is largely inaccurate; interpersonal crime rates in RRR areas are much higher than is commonly believed. ${ }^{13}$

Research indicates that structural and social barriers that form part of the 'architecture of rural life' heighten the risk of family violence. ${ }^{14}$ In particular, geographical isolation and lack of access to appropriate legal and social support can amplify the control exerted by the perpetrators to keep women in violent relationships. ${ }^{15}$ Lack of social services - including, but not limited to, family violence specialist services in RRR communities force women to leave their homes and communities in order to access appropriate services and support. ${ }^{16}$ Despite an understanding of these barriers within the literature, in practice, laws and policies addressing family violence in the rural context have largely ignored or downplayed their importance. As Owen and Carrington note:

In particular, approaches to DV (domestic violence) have generally assumed that rural women have access to wide-ranging and specialist services and referral points such as General Practitioners, 24 hour police stations, housing, public and private transport, and employment opportunities within close proximity. If only. ${ }^{17}$

Indeed, for many women, leaving their home and community is not an option due to lack of available public or private transport, ${ }^{18}$ social support, and economic insecurity. ${ }^{19}$ Even where services are available locally, victims may not be able to or are reluctant to access services due to issues that are magnified in a RRR context, including conflicts of interest, ${ }^{20}$ and a perceived lack of privacy and anonymity. ${ }^{21}$

Women may also be less likely to disclose incidences of family violence due to a 'rural culture' that emphasises family, self-reliance and pride. ${ }^{22}$ For example, drawing on interviews with 49 service providers in RRR areas in Australia, Owen and Carrington found that shame around being a victim of family violence encourages women to remain silent, since disclosure may result in gossip and negative social stigmas associated with being a divorcee. ${ }^{23}$ They also highlight the importance of family privacy, the semblance of a harmonious family and protecting the family's reputation as social factors that deter disclosure in RRR communities. ${ }^{24}$

Other social problems particular to RRR areas may also exacerbate the risk of family violence, including alcoholism, and differing notions of masculinity and gender roles. ${ }^{25}$ For example, DeKeseredy highlights that social practice in rural areas where 'more people are likely to know each other's businesses' can

\footnotetext{
${ }^{12}$ See, eg, Women's Services Network, ‘Domestic Violence in Regional Australia: A Literature Review’ (Report prepared for the Commonwealth Department of Transport and Regional Services, 2000), which finds that family violence was more prevalent in rural and remote communities. However, for a contrary view, see, John Henstridge et al, 'Analysis of the 2005 Personal Safety Survey’ (Report prepared for Families, Community Services and Indigenous Affairs, June 2007).

${ }^{13}$ Santi Owen and Kerry Carrington, 'Domestic Violence (DV) Service Provision and the Architecture of Rural Life: An Australian Case Study’ (2015) 39 Journal of Rural Studies 229, 229, DOI:10.1016/j.jrurstud.2014.11.004, noting wide ranging studies from Australia and other jurisdictions on this point.

${ }^{14}$ Kerry Carrington, 'Violence and the Architecture of Rural Life' in John Scott et al (eds), Rural Crime in Australia (Federation Press, 2007) 86.

15 Sarah Wendt, Domestic Violence in Rural Australia (Federation Press, 2009) 30. See also The National Council to Reduce Violence Against Women and their Children, above n 2, 30.

${ }^{16}$ Dale Bagshaw et al, 'Reshaping Responses to Domestic Violence: Final Report' (University of South Australia, 2000).

${ }^{17}$ Owen and Carrington, above n 13, 237

18 Ibid.

${ }^{19}$ Angela Ragusa, 'Rural Australian Women's Legal Help Seeking for Intimate Partner Violence: Women Intimate Partner Violence Victim Survivors' Perceptions of Criminal Justice Support Services' (2012) 28 Journal of Interpersonal Violence 658, 698-707, DOI: 10.1177/0886260512455864, noting that for victims of family violence in RRR areas, high levels of caretaker responsibility and low levels of socioeconomic support prevented women from seeking legal help, as did prior negative experiences with the police and economic insecurity. Her research was based on questionnaires and interviews, with a sample of 36 participants.

${ }^{20}$ Conflicts of interest may arise, for example, where the victim is seeking the legal services of a professional who is already acting for the perpetrator.

${ }^{21}$ Anthony Morgan and Hannah Chadwick, 'Key Issues in Domestic Violence' (Research Practice No 7, Australian Institute of Criminology, 2007). See also Ragusa, above n 19.

22 Russell Hogg and Kerry Carrington, Policing the Rural Crisis (Federation Press, 2006) 149-159.

${ }^{23}$ Owen and Carrington, above n 13.

24 Ibid.

${ }^{25}$ Carrington, above n 14.
} 
perpetuate a cycle of violence. ${ }^{26}$ Male perpetrators of violence can rely on male friends to support and legitimise their actions, while women are afraid to report violence to local police knowing that they are friends with the abuser. ${ }^{27}$ The existence of these community norms and the silent acceptance of violence by authorities in RRR communities make it difficult for women to publicly disclose their experiences of violence. ${ }^{28}$

Those living in RRR communities on a temporary partner visa face additional barriers to leaving violent relationships. Immigrant women are typically financially and socially dependent on their Australian sponsor or are threatened with deportation if they choose to leave the relationship. ${ }^{29}$ Other barriers for immigrant women include a lack of knowledge of Australia's legal system ${ }^{30}$ and fear of ostracism and shame in their own communities, where divorce or separation may be frowned upon due to religious or social beliefs. ${ }^{31}$ Immigrant women may also lack English ability, social support networks and may have difficulty in finding employment that allows them to leave relationships in a financially secure manner. ${ }^{32}$

\section{The family violence exception in migration law}

The Migration Act 1958 (Cth) and the Migration Regulations 1994 (Cth) provide for a range of partner visas that allow immigrant women to enter and remain in Australia on the basis of their married or de facto relationship with an Australian citizen or permanent resident. ${ }^{33}$ Immigrant women must hold a temporary partner visa for a probationary period of two years, after which a permanent visa is granted if the relationship remains 'genuine and continuing'. ${ }^{34}$

There are a number of exceptions that allow the grant of a permanent visa within the two-year probationary period. ${ }^{35}$ One of these is known as the 'family violence exception'. ${ }^{36}$ Introduced in 1991 , the exception addressed community concerns that 'some migrants might remain in abusive relationships because they believe that they will be forced to leave Australia if they end the relationship'. ${ }^{37}$ The policy intention is to empower victims to leave violent relationships without putting their migration status in jeopardy. ${ }^{38}$

Providing protection to victims of family violence must be balanced with mechanisms to prevent misuse of the exception as a means to access permanent residency. To ensure that only genuine claims of family violence are considered, the Regulations require minimum evidentiary requirements to be submitted before a claim against the family violence exception can be considered. These are discussed below.

${ }^{26}$ Walter S DeKeseredy, 'New Directions in Feminist Understandings of Rural Crime’ (2015) 39 Journal of Rural Studies 181.

${ }^{27}$ Sarah Wendt, 'Constructions of Local Culture and Impacts on Domestic Violence in an Australian Rural Community' (2009) 25 Journal of Rural Studies 175, 181. Wendt notes that constructions of 'mateship' in rural Australia allow men to continue perpetrating violence because their families, friends or communities do not challenge their actions. See also, Walter S DeKeseredy and Martin Schwartz, Male Peer Support and Violence Against Women: The History and Verification of a Theory (Northeastern University Press, 2013), labeling this phenomenon as 'patriarchal male peer support'.

${ }^{28}$ See, eg, Walter S DeKeseredy and Martin D Schwartz, 'Separation/Divorce Sexual Assault in Rural Ohio: Survivors' Perceptions' (2008) 36 Journal of Prevention \& Intervention in the Community 105, DOI: 10.1080/10852350802022365; Alyce LaViolette and Ola Barnett, It Could Happen to Anyone: Why Battered Women Stay (SAGE Publications, $3^{\text {rd }}$ ed, 2014).

29 The National Council to Reduce Violence against Women and their Children, above n 2, 2.5; Family Law Council of Australia, 'Improving the Family Law System For Clients from Culturally and Linguistically Diverse Backgrounds' (prepared for the Attorney-General of Australia, February 2012) [2.2.10].

${ }^{30}$ See, eg, Rochelle Braff and Isobelle Barrett Meyering, 'Seeking Security: Promoting Women's Economic Wellbeing Following Domestic Violence' (prepared for the Australian Domestic and Family Violence Clearinghouse, March 2011) 10, highlighting that 'a number of women in this study found 'information about migration and visa processes confusing'.

${ }^{31}$ See ALRC, 'Family Violence and Commonwealth Laws' (Discussion Paper No 76, 2011) 689.

32 Edwin Odhiambo-Abuya, 'The Pain of Love: Spousal Immigration and Domestic Violence in Australia: A Regime in Chaos?' (2003) 12 Pacific Rim Law \& Policy Journal 673, 698.

33 These visas can be applied for onshore (Subclass 820/801) and offshore (Subclass 309/100). The definition of 'de facto' in the Migration Act also encompasses same-sex relationships: $\mathrm{S} 5 \mathrm{CB}$.

${ }^{34}$ See Migration Regulations 1994 (Cth) sch 2 cl 801.221.

35 Exceptions also exist if the sponsoring partner has died or there is a child of the relationship in relation to whom the applicant has access, custody or joint custody or has a residence order or contact order made under the Family Law Act 1975. See, eg, Migration Regulations 1994 (Cth) sch 2 cl 801.221(3)(a).

${ }^{36}$ Migration Regulations 1994 (Cth) div 1.5 'Special Provisions Relating to Family Violence'.

${ }^{37}$ Department of Immigration and Border Protection, Factsheet: Family Violence Provisions (2015) <http://www.border.gov.au/about/corporate/information/fact-sheets/38domestic>.

${ }^{38}$ Mary Crock and Laurie Berg, Immigration Refugees and Forced Migration: Law, Policy and Practice in Australia (Federation Press, 2011) 195. 
Cases involving the family violence exception arise in a small percentage of partner visa cases. The number of claims has remained consistent over the last few years. ${ }^{39}$ For the financial year 2014-2015, 458 claims of family violence were made to the Department of Immigration and Border Protection from a total of 47,825 partner visas granted. ${ }^{40}$ However, the statistics do not show the percentage of family violence claims made by those who live in RRR communities. Given the fact that family violence is often underreported across Australia, and that significant barriers to disclosure exist for those RRR communities, the figures may not fully reflect the extent of the problem. ${ }^{41}$

\section{Judicially determined evidence of family violence}

The Regulations prescribe two evidentiary options for supporting a claim to access the family violence exception: judicially determined and non-judicially determined. The visa decision-maker cannot consider a claim of family violence unless evidence has been presented in accordance with the legislative requirements.

For judicially determined claims, the alleged victim (either the visa holder or a member of the family unit of the visa holder) is taken to have suffered family violence committed by the alleged perpetrator if the following evidence is presented:

- $\quad$ on the application of the alleged victim, a court has granted an injunction under paragraph 114(1)(a), (b) or (c) of the Family Law Act 1975 against the alleged perpetrator; ${ }^{42}$ or

a court has made an order under State and Territory law against the alleged perpetrator for the protection of the alleged victim; ${ }^{43}$ or

- if a court has convicted the alleged perpetrator of an offence against the alleged victim or recorded a finding of guilt against the alleged perpetrator in respect of and offence of violence against the alleged victim. ${ }^{44}$

In all the instances referred to above, it is also a requirement that the violence, or part of the violence, must have occurred while the marriage or de facto relationship existed between the parties. ${ }^{45}$

If the visa decision-maker is presented judicially determined evidence of family violence, he or she must find that the applicant has suffered family violence for the purposes of the application, and proceed to determine the case on that basis. ${ }^{46}$ These provisions reflect the policy, quite sensibly, that visa decisionmakers should not look behind orders of a court that has determined the existence of family violence. In practice, where judicially determined evidence is presented in accordance with the legislative requirements, the victim will be granted a permanent visa.

\section{Non-judicially determined evidence of family violence}

The ability to submit 'non-judicially determined' evidence of family violence was first introduced in 1995 in response to community concerns that not all immigrant women were able to access the judicial system. ${ }^{47}$ The intention was to increase the accessibility of the family violence exception by allowing for a wider range of evidence to be accepted. These provisions have been amended many times, most recently in 2012 in response to recommendations made by the ALRC. ${ }^{48}$

The Regulations provide that, where a valid non-judicially determined claim of family violence has been made, the visa decision-maker must determine, on the available evidence, whether the victim has suffered 'relevant family violence' as defined by the Regulations. ${ }^{49}$ If the decision-maker is satisfied on the evidence

\footnotetext{
39 Department of Immigration and Border Protection, ‘Annual Report 2014-15' (2015) 68. There were 746 claims made in 2013-14 and 867 in 2012-13.

40 lbid.

41 See eg, Patricia Easteal, ‘Double Jeopardy: Violence Against Immigrant Women in the Home’ (1996) 46 Family Matters 26. DOI: $10.1891 /$ vivi.17.4.455.33680.

42 Migration Regulations 1994 (Cth) reg 1.23(2).

43 Ibid reg 1.23(4).

44 Ibid reg $1.23(6)$.

45 Ibid regs $1.23(3),(5),(7)$.

${ }^{46}$ Ibid regs $1.23(2),(4),(6)$.

${ }^{47}$ See Mary Crock, 'Women and Migration Law' in Patricia Easteal (ed), Women and the Law in Australia (Lexis Nexis Butterworths, 2010) 334.

48 ALRC, above n 2.

${ }^{49}$ Migration Regulations 1994 (Cth) reg 1.23(10)(a). If the evidence presented does not meet the evidentiary threshold for a non-judicially determined claim, the decision-maker cannot consider the claim of evidence and cannot make a finding as to whether 'relevant family violence' has occurred. It is also worth emphasising that the definition of
} 
presented that the alleged victim has suffered 'relevant family violence', he or she must proceed to determine the case on that basis. ${ }^{50}$ If not so satisfied, the decision-maker must seek the opinion of an 'independent expert' - defined in a legislative instrument to be LSC Psychology ${ }^{51}$ - as to whether 'relevant family violence' has occurred. Once sought, an opinion of the independent expert must be taken as correct for the purposes of the visa assessment. ${ }^{52}$

\section{Acceptable evidence prior to 24 November 2012}

Prior to 24 November 2012, a visa holder could make a valid non-judicially determined claim of family violence by submitting a statutory declaration detailing the allegation of family violence along with two statutory declarations from a 'competent person'. ${ }^{53}$ Alternatively, the person's own statutory declaration could be accompanied by a statutory declaration by a 'competent person' along with a police record of assault. ${ }^{54} \mathrm{~A}$ 'competent person' was defined by the Regulations to include a: registered medical practitioner; registered psychologist; registered nurse; social worker; consultant under the Family Law Act; and a manager or coordinator of a crisis or counselling services that specializes in family violence. ${ }^{55}$

The Regulations contain strict requirements around the content of statutory declarations. For example, a statutory declaration of a competent person must have included: the basis of the person's claim to be a competent person; their opinion that the alleged victim has suffered 'relevant family violence'; name the person who committed the family violence; and set out the evidence on which the person's opinion is based. ${ }^{56}$ These strict requirements have resulted in judicial interpretations that have favoured form over substance. Relatively innocuous departures from the prescriptive requirements have rendered invalid a nonjudicially determined claim of family violence. For example, claims were rejected on the basis that a statutory declaration was: made on a state instead of a federal statutory declaration form ${ }^{57}$ signed on one day and witnessed on another; ${ }^{58}$ or simply recited the possession of an opinion rather than clearly expressing an opinion. ${ }^{59}$

While these decisions ensured that the family violence exception was not open to abuse, they confirmed 'unconscionable rigidities in the law' that many viewed as a 'triumph of form over substance'.$^{60}$ This raised questions about whether the provisions were unduly hindering the accessibility of the family violence exception. ${ }^{61}$

In the ALRC Report, the Commission recommended that, for non-judicially determined claims, a visa holder should be able to submit any form of evidence in support of their family violence claim. ${ }^{62}$ It also recommended the repeal of the provisions governing the content of statutory declarations of 'competent persons', and that the Immigration Department's policy manual be amended to reflect that evidence other than from competent persons be given appropriate weight. ${ }^{63}$ The ALRC's recommendations were aimed at removing rigidities in the law while preserving the integrity of the visa system. For this reason, the ALRC did not recommend the repeal of the requirement to seek an opinion of an independent expert where the visa decision-maker was not satisfied that family violence has occurred.

'relevant family violence' particular to the Regulations is different to the definition of family violence in other areas of Australian law.

${ }^{50}$ Ibid reg 1.23(10)(b).

51 IMMI 13/023 Specification of Organisations (reg 1.21). See, LSC Psychology, LSC Psychology <http: / / lscpsych.com.au>. For applications made prior to 3 April 2014, the independent expert was specified as the Department of Human Services. In practice, the independent expert is a senior social worker within the Department.

${ }^{52}$ Migration Regulations 1994 (Cth) reg 1.23(10)(c)(i)-(ii).

${ }^{53}$ Ibid regs 1.23(9), 1.24(1)(a).

${ }^{54}$ Ibid regs 1.24(1)(b), 1.24(2).

${ }^{55}$ Ibid reg 1.21

${ }^{56}$ Ibid regs $1.26(\mathrm{a})-(\mathrm{g})$.

${ }^{57}$ Mohamed v Minister for Immigration and Citizenship (2007) 96 ALD 114.

${ }^{58}$ McGuire v Minister for Immigration and Indigenous Affairs [2004] FMCA 1014 (2004) [24].

${ }^{59}$ See, eg, Minister for Immigration and Citizenship v Ejueyitsi (2007) 159 FCR 94, [35]-[36], citing Ibrahim v Minister for Immigration and Multicultural and Indigenous Affairs [2002] FCA 1279, [43] ('Ibrahim'). In Ibrahim, the court held that statutory declaration from a doctor that stated: 'based on my full clinical assessment, I am of the opinion that $\mathrm{Mr}$ Ibrahim most likely suffered from family violence' did not meet the legislative requirements. Rather, it was no more than a 'trust me' statement, which did not express an opinion as required by the legislation.

${ }^{60}$ Crock, above n 47, 336. See also, Ibrahim FCA 1279; Camak v Minister for Immigration and Multicultural and Indigenous Affairs (2003) 135 FCR 183, [14]-[15].

${ }^{61}$ See ALRC, 'Family Violence and Commonwealth Laws-Immigration Laws' (Issues Paper No 37, 2 March 2011).

${ }^{62}$ ALRC, above n 2, 534 (Recommendation 21-3).

${ }^{63}$ Ibid Recommendation 21-4 and 21-5). 


\title{
Acceptable evidence post 24 November 2012
}

The ALRC's recommendations have not been implemented in full. Instead, the Regulations were amended, with effect from 24 November 2012, to remove references to 'competent persons' and to ostensibly widen the pool of acceptable evidence that could be presented. ${ }^{64}$ For cases post 24 November 2012 , a valid nonjudicially determined claim must include evidence that:

- the alleged victim and alleged perpetrator have made a joint undertaking to a court in relation to proceedings in which an allegation is before the court that the alleged perpetrator has committed violence against the alleged victim; or

- $\quad$ is in accordance with evidentiary requirements set out regulation $1.24 .^{65}$

Regulation 1.24 provides that evidence required to make a non-judicially determined claim must include a statutory declaration from or made on behalf of the alleged victim, and 'the type and number of items of evidence specified by the Minister by instrument in writing for this paragraph' ${ }^{66}$ The relevant legislative instrument - IMMI $12 / 116^{67}$ - provides that an application must be accompanied by at least two items from a list of 'acceptable evidence' provided in schedule 1, and that no more than one type of evidence may be presented. The list of persons who can give 'acceptable evidence' mirrors the previous list of 'competent persons' with the addition of school counsellors or school principals and witnesses who made statements to police during the course of a police investigation. ${ }^{68}$

For each type of 'acceptable evidence', IMMI 12/116 requires that it 'include certain details'; for example, a medical report must identify the alleged victim and detail the physical injuries or treatment for mental health that is consistent with the claimed family violence. ${ }^{69}$ A statutory declaration made by a registered psychologist must 'state in their opinion that the alleged victim was subject to family violence; detail their opinion; and identify the alleged perpetrator'. ${ }^{70}$

\section{Reforms entrench rather than remove barriers for women in RRR communities}

While the 2012 amendments appear, on the surface, to increase accessibility to the family violence exception, commentators have expressed concerns that the new amendments 'could be similarly problematic given the specificity and complexity of the new requirements, which are also not easily accessible'. ${ }^{71}$ That is, while references to 'competent persons' have been removed from the legislation, IMMI $12 / 116$ is just as prescriptive about who can give evidence and what the evidence must include by way of content. In this sense, the reforms can be viewed as cosmetic rather than substantive in nature.

\section{False premise of access to services}

Much like the previous 'competent persons' regime, IMMI 12/116 continues to rely on the false assumption that immigrant women in RRR communities can easily access legal, professional and other social support services that would enable them to submit the 'acceptable evidence' required to access the family violence exception. No concessions are made for their locational disadvantage and vulnerabilities referred to above. The plight of immigrant women in RRR areas seeking to access the family violence exception were neatly encapsulated in a case study provided to ALRC's Inquiry from Visa Lawyers Australia:

\begin{abstract}
In a recent case, an applicant in a regional area was unable to find two suitable competent persons who were willing to provide statements on her behalf. Despite the genuineness of her claim it took her months of searching to find health professionals willing to assist her. The applicant lived in a small town and her doctor, the only competent person she knew, refused to provide a statement because the perpetrator was known to her, and she did not wish to become involved. There were few other health professionals in the area and of those it took the applicant weeks to get into see them, where again they refused to assist her. In the end the applicant was forced to travel some distance from her home to find suitable competent witnesses. Each time
\end{abstract}

\footnotetext{
${ }_{64}^{64}$ Migration Legislation Amendment Regulation 2012 (No 5) (Cth) schs 2-7.

${ }^{65}$ Migration Regulations 1994 (Cth) reg 1.23(9).

66 Ibid reg 1.24(a), (b).

${ }^{67}$ IMMI 12/116 - Specification of Evidentiary Requirements (F2012L02237).

68 Ibid sch 1.

69 Ibid.

70 lbid.

${ }^{71}$ Lauren Gray, Patricia Easteal and Lorana Bartels, 'Immigrant Women and Family Violence: Will the New Exceptions Help or Hinder Victims' (2014) 39 Alternative Law Journal 167.
} 
the applicant was forced to recount her story and request assistance recreating the trauma for the applicant. ${ }^{72}$

As such, the 2012 reforms provide little assistance to those in RRR communities. Rather, they entrench the perverse situation where a person who is unable to provide evidence from two different professionals is precluded from accessing the family violence exception, notwithstanding the availability or strength of other available evidence. For example, evidence from close friends or neighbours who may have witnessed the family violence first-hand remain excluded and hold no weight unless also accompanied by other forms of 'acceptable evidence'. ${ }^{73}$

Requiring evidence from two different professionals may prove an insurmountable hurdle for those in RRR communities. Confining 'acceptable evidence' to a limited range of professionals also increases the likelihood that the victims will be unable to obtain evidence due to problems with confidentiality and anonymity and thereby extend the period of time they remain in a violent relationship.

Further, the amendments do not appear to give the courts any leeway to find that substantial compliance with IMMI 012/116 will be sufficient to meet the minimum evidentiary requirements. As noted above, courts have found that minimal departures from the legislative requirements governing statutory declarations of 'competent persons' sufficient to invalidate non-judicially determined claims of family violence. Since IMMI 012/116 is similarly prescriptive and mandates that statutory declarations include 'certain information', there is little reason to suggest that the courts will take a different approach to the minimum evidentiary requirements. ${ }^{74}$

The likely result is a legal framework that entrenches the vulnerable position of immigrant women in RRR communities rather than empowering them to leave violent relationships. It remains the case that a visa applicant cannot access the family violence exception unless, as Crock notes, 'the applicant complies with the letter of the law both in terms of the qualification of the experts attesting to the evidence and the words used by the experts to describe what has occurred'. ${ }^{75}$

\title{
Consistent decision-making and procedural fairness
}

The current requirement to seek the opinion of an 'independent expert' - LSC Psychology (and previously, a social worker within the Department of Human Services) - if a visa decision-maker is not satisfied on the evidence presented that 'relevant family violence' has occurred, appears sensible. However, a deeper inquiry suggests that it has problems in practice.

Stakeholders to the ALRC's Inquiry expressed concerns about the ability of independent experts to provide consistent, fair and just outcomes. These were neatly summarised by a submission from the Refugee and Immigration Legal Service:

\begin{abstract}
The process undertaken by the independent expert is not subject to any scrutiny, they are not required to provide reasons for their decision, there is no process for seeking a review of their assessment, other than the expensive and limited provision for judicial review. The independent experts are not trained in obtaining evidence. In our experience the quality of the process and assessment by the independent expert varies greatly from person to person. There is very little consistency in their approach. ${ }^{76}$
\end{abstract}

Others lamented the fact that independent experts did not apply the law correctly, or went beyond their mandate in assessing the genuineness of the relationship, rather than assessing whether relevant family violence has occurred. ${ }^{77}$

\footnotetext{
72 Visa Lawyers Australia, 'Submissions No 76 to the ALRC, Inquiry into Family Violence and Commonwealth Laws' <https://www.alrc.gov.au/sites/default/files/pdfs/CFV\%2076\%20Visa\%20Lawyers\%20Australian\%20for\%20web.pdf>.

73 This can be contrasted with refugee claims based on family violence, where no restrictions are placed on what types of evidence can be presented to support a claim. Rather, decision-makers are to assess all of the evidence presented and are able to make credibility assessments when deciding to grant or refuse the visa. Where a claim is made without any corroborative independent evidence, the victim will have a harder time convincing the decision-maker that family violence has occurred.

${ }^{74}$ To date, there has been no judicial consideration of the evidentiary requirements under IMMI $012 / 116$.

${ }^{75}$ Crock, above n 47, 336.

${ }^{76}$ Refugee and Immigration Legal Service, 'Submission No 34 to the ALRC, Inquiry into Family Violence and Commonwealth Laws' (12 April 2011).

77 ALRC and NSWLRC, above n 2, 531.
} 
Two clear problems exist with the independent expert regime. First, independent experts are not legally trained and are being asked to apply a legal definition of 'relevant family violence' that may be foreign to them. It is important to note that, for the purposes of non-judicially determined claims of family violence, the Regulations require a finding that the applicant has suffered 'relevant family violence'. This is different from the definition of 'family violence' in the Family Law Act 1975 (Cth) and other pieces of Commonwealth legislation. ${ }^{78}$ A psychologist employed by LSC Psychology may have an understanding of family violence derived from their practice in the family law or psychology/medical context, or from their own experience, but may not be able to correctly apply the law in the migration context. ${ }^{79}$ Similar problems with incorrect application of the law have arisen in other areas of the migration system, such as health assessments, where decisions have also been outsourced to independent third parties who are not legally trained. ${ }^{80}$

Secondly, there is nothing in the Regulations that requires the independent expert to afford the alleged victim procedural fairness. For example, there is no obligation on the independent expert to obtain oral or other evidence from the applicant, nor is there any requirement in the legislation for the independent expert to give reasons for their assessment to the applicant. Case law suggests that, where the independent expert has not afforded the applicant with procedural fairness, the visa decision-maker (or Administrative Review Tribunal on review) is obliged to refer the matter back to the independent expert to correct any defects. ${ }^{81}$ Similarly, the AAT must not take as correct an opinion of an independent expert who has incorrectly applied the law. In both instances, it is incumbent on the relevant visa decision-maker to refer the matter back to the independent expert for further consideration or for the alleged victim to take the matter on judicial review. This may result in further delay and prolonged trauma for alleged victims, and heightens the risk of them remaining in violent relationships until their migration status is determined. The situation is neither efficient nor ideal.

\section{A new system}

In a discussion paper prior to its final Report, the ALRC proposed a new model for dealing with nonjudicially determined family violence claims with two central features: the removal of minimum evidentiary requirements required to make a valid non-judicially determined claim of family violence; and replacing the 'independent expert' with an 'independent expert panel' scheme. ${ }^{82}$ However, the ALRC did not follow through with this proposal in its final report on the basis that it only had cautious stakeholder support. ${ }^{83}$ Nonetheless, the ALRC report noted that the idea had 'some merit' and that issues relating to the composition of the panel and its operations needed further exploration. ${ }^{84}$

In this section, I will revisit and build on the ALRC's proposal for an independent expert panel. In particular, I argue that IMMI 12/096 should be repealed in favour of an independent expert panel that consists of, at a minimum, a number of CLCs and FVCs around Australia. CLCs and FVCs are leveraging the use of technology and building integrated service mechanisms to provide family violence assistance to those in RRR

\footnotetext{
${ }^{78}$ Definitions of family violence differ across medical, social science and legal spheres. See Family Law Council of Australia, 'Improving Responses to Family Violence in the Family Law System: An Advice on the Intersection of Family Violence and Family Law Issues’ (December 2009) 23-26. Section 4AB(1) of the Family Law Act defines family violence by reference to 'violent, threatening or other behavior by a person that coerces or controls a member of the person's family (the family member), or causes the family member to be fearful'. In contrast, reg 1.21 of the Migration Regulations defines 'relevant family violence' to mean 'conduct, whether actual or threatened towards the alleged victim ... reasonably fear for, or to be reasonably apprehensive about, his or her own wellbeing or safety'. The difference is that the Family Law Act definition requires a finding that the family member is fearful of the perpetrators' conduct, while the Migration Regulations only require a finding that the person is reasonably fearful or reasonably apprehensive about his or her safety or wellbeing as a result of the conduct.

79 Interestingly, a number of elements of the definition of 'relevant family violence' are not further defined by the Regulations. These include what it means to be 'reasonably fearful' or 'apprehensive' about one's 'wellbeing' or 'personal safety'.

${ }^{80} \mathrm{See}$, eg, Norman Seligman v Minister for Immigration and Multicultural Affairs [1998] 54 ALD 761, where it was found that a jurisdictional error arose because the Medical Officer of the Commonwealth had applied the incorrect test as set out in Public Interest Criterion 4005.

${ }^{81}$ Minister for Immigration and Citizenship v Maman [2012] 200 FCR 30. This is due to the fact that the Tribunals and visa decision-maker owes procedural fairness to the applicant.

${ }^{82}$ ALRC, above n 31, 734-5.

${ }^{83} \mathrm{~A}$ number of stakeholders were provided in principle support to the independent expert panel but some cautioned that deeper consideration was required before a recommendation could be made. See ALRC and NSWLRC (2010), above $\mathrm{n} 2$, 537.

84 Ibid 534.
} 
communities. It is argued that by leveraging these innovations and practices, the panel scheme can address the locational disadvantage for those in RRR communities.

\section{Removing minimum requirements of 'acceptable evidence'}

Under the proposed model, if a person cannot present judicially determined evidence of family violence, their claim is referred to an expert panel for assessment. Similar to the ALRC's initial proposal, the alleged victim would be able to submit any evidence to the panel in support of a non-judicially determined claim of family violence. ${ }^{85}$ As the ARLC argued:

if the system envisages that visa decision-makers are not adequately equipped to make assessments in relation to family violence, this should result in a complete, rather than partial, removal from the assessment process in deference to an independent expert panel. ${ }^{86}$

For those in RRR communities, the benefit of such an approach is obvious: it increases access to the family violence exception by allowing all non-judicially determined claims to be considered, not just those who are able to provide minimum forms of 'acceptable evidence'. The implication is that an independent expert panel would consider family violence claims holistically, taking into account any evidence presented, the person's circumstances and background and credibility. Particularly for those in RRR communities, this is a more desirable position than the current system.

Another benefit of removing minimum requirements of acceptable evidence is that it 'streamlines' the system by reducing the number of times a person has to disclose their experiences of family violence. ${ }^{87}$ Under this model, victims will not need to visit - and perhaps revisit - professionals in order to ensure that their statutory declarations meet the legislative criteria before a claim is considered. Claims can be quickly referred to the panel for assessment and potentially reduce the time that a victim needs to remain in a violent relationship before securing a migration outcome that would empower them to leave.

\section{Composition and operation}

The ALRC emphasised that the composition of an independent expert panel would be important, but it did not elaborate on precisely how it would operate in practice. The Department of Immigration suggested that a national organisation 'which employs appropriate professionals could conduct interviews nationally and provide reports to visa decision-makers' ${ }^{88}$ Other stakeholders suggested that the government could appoint a number of individuals around the country to the panel, based on 'their experience and expertise in dealing with family violence claims' ${ }^{89}$ Alternatively, an independent expert panel could be established within the Department of Immigration and Border Protection as a specialist decision-making unit. Lastly, the panel could comprise of one or more organisations external to the government.

I suggest that an independent expert panel should, at a minimum, consist of a number of CLCs and FVCs around the country. There are a number of benefits to this approach over other methods of composition, both for those in RRR communities and for other victims of family violence more broadly.

\section{Leveraging integrated services}

First, appointing CLCs and FVCs to an independent expert panel scheme allows for the system to leverage the benefits of growing integrated service delivery within the sector. Both the ALRC and Australian Human Rights Commission have stressed the importance of integrated systems that provide for 'one-stop shop' or 'inter-agency collaboration' that allow victims to address a number of problems associated with family violence in one place..$^{90}$ In its report, the Improving the Family Law System for Clients from Culturally and Linguistically Diverse Backgrounds, the Family Law Council also expressed the need for 'greater collaboration between family law systems' and pointed to outreach work done by CLCs within health and migrant services sector as an example of such collaboration. ${ }^{91}$ Similar recommendations for enhanced

\footnotetext{
${ }^{85}$ Ibid 520-525. Removing minimum evidentiary threshold is also consistent with approaches taken in the UK and Canada.

${ }^{86}$ ALRC, above $n 32,734$.

${ }^{87}$ ALRC and NSWLRC (2010), above n 2, 537.

88 Department of Immigration and Citizenship, Submission No 121 to the ALRC's Family Violence and Commonwealth Laws Inquiry (2012).

${ }^{89}$ ALRC and NSWLRC (2012), above n 2, [21.105].

90 Ibid rec 29-1; Family Law Council of Australia, above n 29, rec 3.1.

${ }^{91}$ Family Law Council of Australia, above n 29, 3.2.4. Council cited as an example outreach programs conducted by

Women's Legal Services NSW. As part of the program, solicitors attend women's health centres across Western Sydney
} 
integrated services have been made at a state level, in particular to address the needs of RRR communities. ${ }^{92}$

Integrated service delivery is growing at a rapid rate in Australia, and looks set to continue to grow with funding from the Government's $A \$ 100$ million package..$^{93}$ There are many examples of integrated services in CLCs and FVCs - including co-location and outreach models - around Australia. ${ }^{94}$ For example, Women's Legal Services NSW conducts regular outreach program in partnership with other organisations to provide legal advice to women in remote areas. Another growing area is health-justice partnerships, where legal and health organisations are working together to provide legal advice patients in hospitals. ${ }^{95}$ An example of co-location is the Women's Health and Family Services centre in Perth, which provides a 'one-stop shop' through co-location of refuge, legal, family support, police and counselling services. ${ }^{96}$

As integrated service delivery continues to grow, and with adequate funding, psychologists and/or doctors could to be appointed to CLCs or FVCs. Alternatively, they could conduct outreach work within these centres, including assessing family violence claims in RRR communities. If this occurs, referring victims to an expert panel consisting of FVCs and CLCs may help resolve their migration issues, but also trigger a cascade of other services that a family violence victim may require, including health, housing, child protection or other legal issues. This is preferable to the current model, where victims visit professionals for the purpose of obtaining evidence to access the family violence exception, rather than addressing their family violence issues.

Secondly, I argue that CLCs and FVCs are better equipped than a single psychologist to provide robust family violence assessments. CLCs and family violence services are already staffed with legal professionals, many of whom have relevant legal expertise and experience in dealing with family violence. Where colocation of services exists, decision quality and consistency should benefit from input of psychologists and/or health professionals. This ensures that family violence claims are considered holistically, taking into account a range of different factors.

Thirdly, appointing CLCs and family violence centres to the panel allows for 'targeted training and education into the nature, features and dynamics of family violence'. ${ }^{97}$ Legal training on how to apply the definition of 'relevant family violence' could be provided to promote consistent decision-making, while also reducing the risk of legal error. Improved expertise of CLCs and FVCs will not only ensure protection of genuine victims of family violence in the long run but, just as importantly, allow the system to reject unmeritorious claims to maintain the integrity of the visa system.

Lastly, I suggest that cases referred to the independent expert panel should be free for alleged victims, recognising that financial barriers exist for those in RRR communities. Further safeguards in relation to procedural fairness could also be considered, including legislative amendments that would require the panel to invite the applicant to give oral evidence (including via phone, teleconference or Skype) and require the panel to give the applicant a statement of reasons for their decision.

once a fortnight to provide legal services on-site. This is said to allow for cross-referrals and legal advice to be provided anonymously to those who otherwise have barriers in seeking legal help.

92 Special Taskforce on Domestic and Family Violence in Queensland, above n 5, Recommendations 72-74. The taskforce recommended that the Queensland government develop a longterm investment and funding model to invest in: enhanced collaboration and coordination; encourage innovation in service delivery; attract and retain highly skilled workers to support family violence victims in RRR communities; and link RRR services to a broader network of family service provider. See also, Western Australia Department of Child Protection and Family Support, 'Western Australia's Family and Domestic Violence Prevention Strategy to 2022: Creating Safer Communities’ (2013) 11. Action area 2.2 emphasises the need to build capacity of service responses for those in RRR communities.

${ }^{93}$ Malcolm Turnbull, Prime Minister, above n 6. The package includes $\$ 15$ million to establish 'specialised domestic violence units to provide access to coordinated legal, social work and cultural liaison services for women in a single location, and allow legal services to work with local hospitals, including for women from culturally and linguistically diverse communities and women living in regional/remote areas.

94 See ALRC and NSWLRC (2010), above n 2, ch 29 provides a good summary of integrated responses across states and territories.

95 For an overview of health-justice partnerships, see Justice Connect, Health Justice Partnerships Toolkit (2015) <https://www.justiceconnect.org.au/our-programs/seniors-law/health-justice-partnership/health-justicepartnerships-toolkit>. An example of a partnership is the HeLP legal clinic at the Alfred Deakin hospital, which provides free legal advice to patients onsite through a partnership with the law firm Maurice Blackburn.

${ }^{96}$ Women's Health and Family Services, About Us <http://whfs.org.au/aboutus>. The Domestic Violence Advocacy Service within the centre is run in partnership with a partnership between Legal Aid WA, CASE for Refugees, WA Police Service, Yorgum Aboriginal Counselling Service, Women's Health and Family Services, Department of Justice and Women's Council For Domestic \& Family Violence Services.

${ }^{97}$ ALRC, 'Family Violence and Commonwealth Laws', above n 31, 735. 


\title{
Leveraging the use of technology
}

One benefit that was not considered by the ALRC was the potential of an independent expert panel to leverage technology as a means of providing access to justice for those in RRR communities.

Increased Internet penetration into rural and remote areas in Australia has closed the 'digital divide' between metropolitan and rural areas. ${ }^{98}$ Over the past decade, the courts have increasingly relied on technology to provide access to justice for those in RRR areas. ${ }^{99}$ Innovative uses of technology include "conducting procedural hearings through tele or video conferencing or "virtual court applications" and facilitating more efficient ways of giving evidence through audio, video, transcript and evidence presentation systems'. ${ }^{100}$ In its 2014 Access to Justice Report, the Australian Productivity Commission highlighted that investment in technology by courts would generate long-term savings and improved access to justice and recommended that courts should extend

\begin{abstract}
their use of telephone conferences and online technologies ... and examine whether there should be a presumption in favour of telephone hearings or the use of online court facilities (where available) for certain types of matters or litigants. ${ }^{101}$
\end{abstract}

Another reason for appointing CLCs and FVCs to an independent expert panel is that, like the courts, they have been willing to embrace innovative uses of technology to improve services to those in RRR communities. For example, under an innovative project entitled 'Women, Lawyers, Workers', three women's health services in conjunction with Women's Legal Services Victoria provide advice to women who are victims of violence via Skype three mornings a week. ${ }^{102}$ Victims can access the Skype service via family violence specialists with a laptop or Ipad at the premises of the agency or be supported at home by a support worker. ${ }^{103}$ The conversations using Skype are encrypted to ensure confidentiality. Women's Health in the North believes that the project has been successful in providing access to justice to those in RRR areas without the need for travel. ${ }^{104}$ In addition, the ability of workers to be able to see non-verbal cues of their clients 'significantly decreases the time it takes to build rapport with women' as compared to the telephone. ${ }^{105}$

Similarly, Women's Legal Services NSW uses technology to provide legal and other information to community workers in NSW who work in family violence. Its website, ASK LOIS (Legal Online Information Service) provides free live webinars on a range of issues relating to family violence. ${ }^{106}$

In 2013, the NSW Government developed, in conjunction with family violence experts, including the NSW Women's Refuge Movement and Women NSW, a mobile phone app (called Aurora) for victims of family violence. ${ }^{107}$ The app provides the user with information about family violence services, support options, and the ability to 'message friends' when they feel threatened or harassed. In 2015, the Australian Government launched another app called DAISY: it also aims to connect women experiencing family violence with local and state services. ${ }^{108}$

These innovative uses of technology provide a template for the operation of CLCs and FVCs as part of an independent expert panel. It is not inconceivable, for example, that a CLC in Sydney could use video conferencing or, through Skype technology, to obtain evidence from alleged victims in the RRR community. Victims could, where they exist, utilise existing remote witness facilities available at local courts, or access

\footnotetext{
${ }^{98}$ Australian Communications and Media Authority, Research Snapshots, Regional Australia in the Digital Economy <http://www.acma.gov.au/theACMA/engage-blogs/engage-blogs/Research-snapshots/Regional-Australia-in-the-digitaleconomy>.

99 See, eg, Anne Wallace, 'Virtual Justice in the Bush: The Use of Court Technology in Remote and Regional Australia' (2008) 19 Journal of Law, Information and Science 1.

100 Productivity Commission, 'Access to Justice Arrangements: Volume 1' (Productivity Commission Inquiry Report No 72, 5 September 2014) 575.

101 Ibid 578, Reccomendation 17.1.

102 See Women's Health in the North, Women, Lawyers, Workers Project (2015)

<http://www.whin.org.au/projects/women-lawyers-workers.html>

103 Productivity Commission, above n 100.

${ }^{104}$ Women's Health in the North, What We Do (2015) <http://www. whin.org.au/what-we-do.html>. Women's Health in the North promotes collaborative partnerships to improve services and programs for women. The program covers a number of municipalities in Northern Victoria.

105 Women's Health in the North, 'Submission No 83 to the Australian Productivity Commissions, Inquiry into Access to Justice Arrangements'.

106 Women's Legal Services NSW, Ask LOIS (2015) Webinars <www.asklois.org.au/webinars>.

107 NSW Government, Domestic and Family Violence App (2015)

<https://www.women.nsw.gov.au/violence_prevention/domestic_and_family_violence_app>.

108 Michaela Cash, New App Connects Women Experiencing Violence to Specialist Support, (Press Release, 5 March 2015).
} 
the panel through local women's health or family violence service, or from home. They may use a family violence app to connect with local services that are able to assist them with using technology or help them to collect evidence. Skype conference calls may also allow expert evidence to be given from a range of service providers or professionals who the alleged victim may have consulted.

\section{Reforms must be considered within a wider context}

While these reforms are likely to increase access to the family violence exception for those in RRR communities, they need to be considered within a wider context of legal and other response to family violence. An independent expert panel of CLCs and FVCs is not a panacea for immigrant women in RRR communities. For example, not all immigrant women will be comfortable with or have access to internet connectivity that would enable them to access online support. ${ }^{109}$

In particular, the independent expert panel scheme does not obviate the need to provide increased access to local social and legal services, better access to courts, better information dissemination and education about family violence, and policies aimed at other root causes of family violence including alcoholism and poverty. ${ }^{110}$ Rather, the creation of a panel should be considered among a range of reforms that improve access to justice for women in rural and remote areas.

\section{Conclusion}

The prevalence of family violence is an ongoing concern for the Australian community. There is now considerable impetus and momentum for legal and practical reforms to address the issue. Within this context, this article has examined the impact of migration laws on immigrant women who are victims of family violence living in RRR communities. Immigrant women living in RRR communities face additional barriers in leaving violent relationships when compared to their urban counterparts, including a lack of access to services, isolation and rural culture that silences women from disclosing family violence.

This paper has argued that Australia's migration laws inadequately account for the locational disadvantage of immigrant women in RRR communities. While the family violence exception in the Migration Regulations provides a pathway out of violent relationships to permanent residency for immigrant women, the law places strict procedural and evidentiary hurdles that disproportionately affect those in RRR communities. In particular, the law assumes that those in RRR communities are able access appropriate professional and other services that would allow them to access the family violence exception. Recent amendments to the Regulations, while well intentioned, have failed to address this problem.

A new approach is needed. This article has called for a revamp of the procedures governing 'non-judicially' determined claims of family violence. Building on the work of the ALRC, it has argued that if a person cannot present judicially determined evidence of family violence, their claims should be referred to an 'independent expert panel' for assessment. That panel should include, at a minimum, a number of CLCs and FVCs around the country. CLCs and FVCs are engaging in innovative uses of technology and engaging in integrated service delivery to improve access to justice for immigrant women in RRR communities. Allowing the migration system to leverage off these innovations can address the locational disadvantage faced by immigrant women in RRR communities while ensuring that their family violence problems are holistically addressed. This will result in increased access to the family violence exception for immigrant women in RRR communities.

While these reforms are important, they are not the panacea for immigrant women in RRR communities. Rather, the reforms should be seen as one area of reform, among many, that are needed address the family violence issue in Australia.

\footnotetext{
${ }^{109}$ Amanda George and Bridget Harris, 'Landscapes of Violence: Women Surviving in Family Violence in Rural and Regional Victoria' (Centre for Rural and Regional Law Justice, 2014) 63.

${ }^{110}$ Australian Government, above n 2.
} 